\title{
ビール中のニトロソアミンとその成因について
}

(昭和 54 年 9 月 28 日受理)

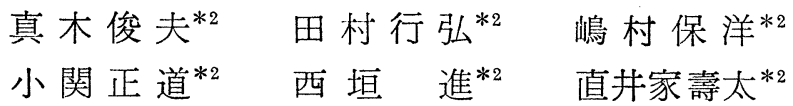

\section{Occurrence of Dimethylnitrosoamine in Commercial Beers and Its Formation in the Brewing Process}

\author{
(Hygienic Studies on $\mathrm{N}$-Nitroso Compound. IV)
}

\section{Toshio Maki, Yukihiro Tamura, Yasuhiro Shimamura, Masamichi Koseki, Susumu NISHIGAKI and Yasuta NAOI}

(Tokyo Metropolitan Research Laboratory of Public Health: 24-1, Hyakunincho 3-chome, Shinjuku-ku, Tokyo)

During the period from February through April, 1979, commercial beers of different types obtained from retailers in Tokyo were examined for the presence of volatile $N$ nitrosamine (NNA).

Detection and determination of NNA were carried out by the use of a thermal energy analyzer coupled with gas chromatography.

It was found that $25(93 \%)$ of 27 samples contained dimethylnitrosamine (DMNA), with a mean level of $1.7 \mathrm{ppb}$; no other NNA was detectable.

The source of the DMNA was investigated, and it was found that relatively high levels of DMNA contamination of malt occurred when the green malt was dried and/or kilned with fuel gas, while lower levels were found in green malt treated with an electric desiccator.

(Received September 28, 1979)

\section{緒言}

発ガン性を有する $N$-ニトロソアミン（以下 NNA と

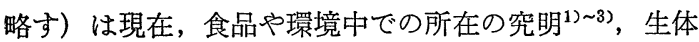
内での NNA 生成 ${ }^{4)}$ (5)を゙に関する調查が行われ国際的 にも公臬衛生上評価が急がれている.

著者ら (6) 8) は, 熱エネルギー分析器による NNA の分 析法を検討するとともに各種市販食品について NNA 含有量の実態調査を行ってきた.その一環として,市販ビ ール中の NNA 含有量の調査を行い, ジメチルニトロソ アミン (以下 DMNA と略す) の存在を認めた。汇とん どのビールから DMNA が検出されたことは,ビールが ヒトによって連続的に多量摂取されるため，そのレベル

*1 $N$ - ニトロソ化合物の衛生学的研究（第 4 報）

*2 東京都立衛生研究所: 東京都新宿区百人町 3-24-1

*3 河端俊治ら: (社) 日本食品衛生学会第 37 回学術講 演要旨集（東京）p. 23，(1979）
は握と成因などの調査が必要と考えられた。

ビール中の NNA に関しては Spiegelhalder ら ${ }^{9)}$, 河 端ら*3が市販ビール中の DMNA の存在を報告している が，その成因について製造工程を順に追って詳細に究明 した報告は見られない。

そこで, 本報は市販ビール中の NNA 含有量調査とビ ール製造工程のいかなる段階で NNA が生成するかを 明らかにする目的で工程別に NNA の検索を行い，また NNA の消長について検討を加えたので報告する.

\section{実験材料と方法}

\section{1. 試料}

1) 1979 年 2 月から 4 月の間に都内で販売されてい た国産ラガービール 11, ラガータイプの生ビール 6, 黒 ビール 5, 輸入ラガービール 4, 黒ビール 1 , 計 27 検体

2) 原料については大麦 (生)，1，乾燥麦芽 7 (a〜 $\mathrm{g})$, コーンスターチ $3(\mathrm{~A} \sim \mathrm{C})$, コーングリット $3(\mathrm{~A} \sim$ 

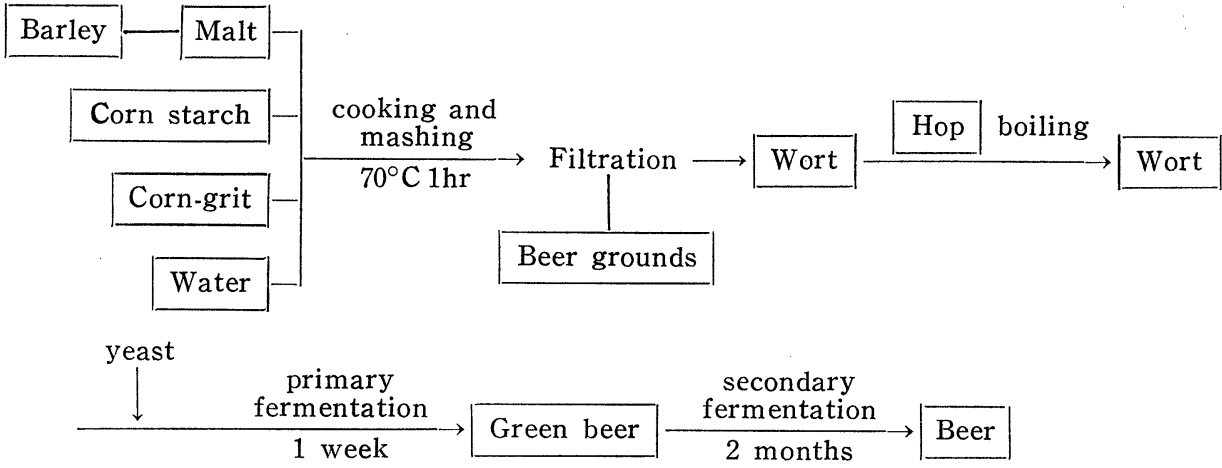

Scheme 1. Brewing process of beer

C), ホップ $3(\mathrm{~A} \sim \mathrm{C})$, 原水 3 , 計 20 検体

3）ビール製造工程別に採取した試料：麦芽汁（者沸 前） 3 , 麦芽汁 (煮沸後) 3 , 若ビール 3 , ビール粕 3 , ラガービール 3 , 同罐入り 3 , 生ビール 3 , 同罐入り 3 , 計 24 検体, 以上合計 69 検体を分析に供した.

\section{2. 試薬}

NNA 標準物質として次の 7 種類を用いた. ジメチ ルニトロソアミン (DMNA), ジェチルニトロソアミン (DENA), ジノルマルプロピルニトロソアミン (Dn・ PNA), ジイソプロピルニトロソアミン (Diso·PNA), ジ ノ゙ルマルブチルニトロソアミン (Dn・BNA), ジイソブチ ルニトロソアミン (Diso·BNA), (イーストマン社製, 95 \%以上）をそれぞれ $0.1 \mathrm{ppm}$ になるようにジクロルメ タンで希釈して用いた。 その他の試薬類はすべて市販特 級品を使用した。

\section{3. 装置}

1) Thermal Energy Analyzer-Gas Chromatograph (以下 TEA.GC と略す): TEA 502 型 ((株)島津 製作所製), GC カラム用充てん剂: $20 \%$ Versamide 900 , 60 80 mesh (Chromosorb W, AW), 5\% OV-17, 60 80 mesh (Chromosorb W, AW), ガラス管 ( $3 \mathrm{~m}$, 内径 $3 \mathrm{~mm}$ ), カラム温度 $180^{\circ}$, 注入口温度 $220^{\circ}$, TEA 分解 炉 $450^{\circ}$, 検出器: TEA ディテクター, キャリアーガス: Ar $60 \mathrm{ml} / \mathrm{min}$., NNA の検出限界は $0.05 \mathrm{ng}$ である.

2) 電気乾燥器および都市ガス焙燥器

電気乾燥器: 温度調節器付 $100 \mathrm{~V},(30 \times 30 \times 30 \mathrm{~cm})$ 焙燥器: 乾燥器型箱の内部にガスバーナーを組み达ませ た. 焙燥する麦芽をのせる金龬の棚はガスバーナーから $15 \mathrm{~cm}$ 離して設置した. 焙燥器の下方からファンで送風 し, 上方に放出し, 内部の加熱温度を一定にした.

\section{NNA の分離抽出法}

1）坂田ら*4の方法に準じて実施した. 細切した試料 $50 \mathrm{~g}$ (液状試料はそのまま) を $300 \mathrm{ml}$ の分液漏斗にとり $20 \%$ 水酸化ナトリウム溶液 $50 \mathrm{ml}$, ジクロルメタン 150

*4 坂田 衛, 籠谷昭一ら：(社) 日本食品衛生学会第33 回学術講演要旨集 (東京), p. 58, (1977) $\mathrm{ml}$ を加え, 振とら器で 5 分間振とら抽出する. これを 2 回繰り返し（必要あれば遠心分離 $2000 \mathrm{rpm}, 3$ 分）有 機層は分取して合わせ, 無水硫酸ナトリウムで脱水後, ガ ラス繊維ロ紙 (No. GB-100R) でろ過し, ろ液をクデル ナ・ダニシュ濃縮管により $37^{\circ}$ の水浴中で $2 \sim 5 \mathrm{ml}$ で濃縮を行い，これを定量用の試験溶液とし，TEA-GC を用いて定量分析を行った.

市販ビール $50 \mathrm{~g}$ に各ニトロソアミン $0.5 \mu \mathrm{g}$ を添 加したときの本定量法の回収率は DMNA で 79\%, DENA, Dn・PNA, Diso・PNA, Dn・BNA および Diso・ BNA でそれぞれ 90\% であった.

2）水分測定：衛生試験法に準じた.

5. ビール製造工程におけるサンプリング

ビール製造工程を Scheme 1 に示した. ロ内は分析に 供した試料を示した。

ビール製造工程上, NNA 生成量の推移を比較するた めに乾燥麦芽, コーンスターチ, コーングリット，ホッ プ, 原水を $\mathrm{A}, \mathrm{B}, \mathrm{C}$ の 3 ロットに分け, 実際の工程に 準じて, ビール A, B , C を作り, NNA 生成に関する 調査を行った.

乾燥麦芽は a から g まで ( $\mathrm{a}, \mathrm{b}$ のみ国内産, 他は輸 入品）の 7 種類を用い, $\mathrm{A}$ 口ットは $\mathrm{a}, \mathrm{b}, \mathrm{c}, \mathrm{f}$ の乾燥 麦芽をそれぞれ $16.4,6.6,38.5,38.5 \%$ の割合で混合 した，B口ットは a, c, d, e, g をそれぞれ 13.1, 20.1, 38.5, 18.5, 9.8\% の割合で, また C ロットは a, b, c, d, e をそれぞれ 9.8, 13, 30, 17.2\% の割合で混合 した.

\section{6. 製 麦 法}

ビールの標準的な製麦法に従い実験的規模で行った.

粒の長さ $2.5 \mathrm{~mm}$ 以下の国内産大麦 (二条) を約 2 倍 量程度の水道水に浸し, 浮いた大麦を取り除き室温で約 1 日水張りを行った. ついで水切りをした後, 再び水を 加光同様の操作を 3 日間繰り返す. 水切り後, 水分を吸 収した大麦をガーゼを敷いたカゴにのせ，水でぬらした ガーゼをかぶせ, 室温 15〜18 で 10 日間かけて発芽さ せ緑麦芽を得た。この緑麦芽を電気乾燥用試料と都市ガ 
ス焙燥用試料に分けた.

温度条件は電気乾燥器中で初期温度 $40^{\circ}$ で約 1 時間保 ち, $50^{\circ}$ に温度を上げ 1 日保温した. 2 日目から $50^{\circ}, 70^{\circ}$, $85^{\circ}$ と 3 時間ごとに段階的に温度を上昇させた。

一方, 都市ガス焙燥は緑麦芽を温度, 加熱時間とも電 気乾燥と同一条件で行った. 実際のラガービールの製造 に使用する緑麦芽の焙燥温度は $85^{\circ}$ にとどめられている こと, その乾燥麦芽の水分含量は $3 \%$ 程度であることか ら, 著者らもこれを目安にした. 緑麦芽执よび各温度条 件で得られた試料の一部を採取し，芽，根を取り除さ，

NNA の分析和よび水分の測定を行った.

\section{結果と考察}

\section{1. 市販ビール中の NNA 含有量}

市販ビール計 27 検体について NNA の分析結果を Table 1 に示した.

国産ラガービール 11 検体の DMNA 含有量の範囲は $0.5 \sim 4.2 \mathrm{ppb}$, 平均 $1.6 \mathrm{ppb}$ であった. 生ビール 6 検体 の DMNA 含有量は痕跡 $2.9 \mathrm{ppb}$, 平均 $1.3 \mathrm{ppb}$ であ った. また黒ビール 5 検体の DMNA 含有量は 0.7 $1.2 \mathrm{ppb}$, 平均 $1.0 \mathrm{ppb}$ でそれぞれの平均含有量に大差は なかった. 次に輸入ラガービール 4 検体の DMNA 含 有量の範囲は $1.3 \sim 6.2 \mathrm{ppb}$, 平均 $3.0 \mathrm{ppb}$ であった。 た黒ビール 1 検体から $1.2 \mathrm{ppb}$ の DMNA を検出し た. DMNA 以外の NNA はいずれのビールからも検出 されなかった。

著者らの分析結果は Spiegelhalder ら ${ }^{9)}$ が報告してい るラガービールの分析值と同じ範囲のものであった.

2. ビール原料中の NNA 含有量分布状況

A，B，Cの 3 ロットに使用した乾燥麦芽 a から g, コーンスターチ, コーングリット，ホップおよび原水中 の分析結果を Table 2 に示した.

乾燥麦芽は全試料から DMNA が検出され，その範囲 は $1.7 \sim 76.7 \mathrm{ppb}$ でかなりの差が見られた。平侍含有量 は $16.4 \mathrm{ppb}$ であり, 市販ビール中の DMNA 含有量の 平均值より約 10 倍高い值であることがわかった. しか 乙, その他の原料からはビールの DMNA 含量に関与す
Table 2. Occurrence of DMNA in Five Materials of Beer

\begin{tabular}{ll|c}
\multicolumn{1}{c|}{ Samples } & & DMNA (ppb) \\
\hline Malt & a & 10.5 \\
& b & 9.1 \\
& c & 10.4 \\
& d & 76.7 \\
& e & 2.9 \\
Corn starch & f & 1.7 \\
& A & 3.7 \\
\hline Corn grit & B & 0.3 \\
& C & 0.3 \\
& A & 0.3 \\
\hline Hop & B & n.d. \\
& C & n.d. \\
& A & n.d. \\
\hline Water & B & n.d. \\
& C & n.d. \\
& A & n.d. \\
\hline & B & n.d. \\
& C & n.d. \\
& & n.d.
\end{tabular}

n.d., not detected

るほどの DMNA は検出されなかった。

\section{3. ビール製造工程別 NNA 含有量分布状況}

Scheme 1 に示した製造工程を追ってサンプリングし た試料中の NNA 分析を行った.

各原料の混合物を $70^{\circ}, 1$ 時間糖化を行った後の $\mathrm{A}$, $\mathrm{B}, \mathrm{C}$ 各ロットの麦汁 (煮沸前) の DMNA はそれぞれ $1.1,1.5,0.8 \mathrm{ppb}$ であった. 一方, ビール粕からは全く 検出されなかった。このことから麦芽中の DMNA はほ とんど全部麦汁に移行するものと思われる.

次に, この麦汁にホップを添加し, 煮沸を行うと約

Table 1. Dimethylnitrosoamine (DMNA) in Beers of Different Types

\begin{tabular}{|c|c|c|c|c|c|c|c|c|}
\hline \multirow{2}{*}{\multicolumn{2}{|c|}{ Type of beer }} & \multirow{2}{*}{$\begin{array}{l}\text { No. of } \\
\text { samples }\end{array}$} & \multicolumn{6}{|c|}{ No. of samples with DMNA concn. (ppb) of DMNA concn. (ppb) } \\
\hline & & & $\begin{array}{c}<0.5 \\
\text { (negative) }\end{array}$ & $0.5 \sim 1.0$ & $1.1 \sim 2.9$ & $\begin{array}{c}3.0 \text { or } \\
\text { more }\end{array}$ & Mean & Maximum \\
\hline \multirow[t]{3}{*}{ Domestic } & Lager beer & 11 & - & 7 & 2 & 2 & 1.6 & 4.2 \\
\hline & Draft beer & 6 & 2 & - & 4 & - & 1.3 & 2.9 \\
\hline & Black beer & 5 & - & 3 & 2 & - & 1.0 & 1. 2 \\
\hline \multirow[t]{3}{*}{ Imported } & Lager beer & 4 & - & - & 2 & 2 & 3.0 & 6.2 \\
\hline & Black beer & 1 & - & - & 1 & 一 & & \\
\hline & All & 27 & 2 & 10 & 11 & 4 & 1. 7 & 6.2 \\
\hline
\end{tabular}


$10 \%$ の水分が蒸発するが，このよらにして得られた麦 汁の DMNA は A，B，C それぞれ $0.9,0.6,0.7 \mathrm{ppb}$ であった，煮沸濃縮による増加は見られず，むしろ減少 が見られた。

さらにこれに酵母を添加し，主発酵で得られる若ビー ル中のDMNA はそれぞれ 0.7, $0.6,0.7 \mathrm{ppb}$ で，前段階 工程の DMNA 值とほとんど差が見られなかった.この 若ビールを 2 か月間熟成（後発酵）させた後 $60^{\circ}, 30$ 分 の加熱殺菌したラガービール大ビン，同午入，加熱しな い生ビール大ビン，同缶入に分け分析した. DMNA は $\mathrm{A} ， \mathrm{~B}, \mathrm{C}$ それぞれ $0.9,0.7,0.9 \mathrm{ppb}, 1.0,0.9,0.8$ $\mathrm{ppb}, 0.8,0.7,0.8 \mathrm{ppb}, 0.8,0.8,0.7 \mathrm{ppb}$ と 12 種の間 には差がなくほぼ同じレベルにあった。

これらの結果から, ビール製造工程上, 糖化の段階, 麦汁から主発酵, 最終製品に至る間に DMNA が生成増 加する要因はないと考えられる.

\section{4. 製麦による NNA 生成量}

国産ビールに使用される乾燥麦芽は通常, 輸入品が 75 80\%（昭和 53 年度 87\%） を占め，諸外国では麦芽 の焙燥にガスバーナーを用いる直火方式でも行われてい る. そこで, 著者らは実験方法 6 の製麦法に従って作っ た緑麦芽について, 電気乾燥と都市ガス焙燥を行い, 得られた試料中の NNA 分析を実施した.その結果を Table 3 に示した. な扮試料中の水分含量が異なるた め DMNA 濃度は乾燥重量に換算して示した。

DMNA が検出されなかった大麦を 13 日間かけて発 芽させ，電気乾燥と都市ガスによる焙燥を試みた．緑麦 芽は焙燥処理を行わない場合でも $1.0 \mathrm{ppb}$ の DNA を検出した. 大麦は発芽しながら生長する段階でタンパ ク分解が起こり，アミンが生成増加するという報告10),11) がある. 特に, Drews ら ${ }^{12)}$ は麦芽中にジメチルアミン のみが生成すると報告していることから，この $1.0 \mathrm{ppb}$ といら值は麦芽中のジメチルアミンと二酸化窒素とが麦

Table 3. Occurrence of DMNA in Barley and Its Malt Dried with Electric Desicator or Kilned with Fuel Gas

\begin{tabular}{lll|cc}
\multicolumn{1}{c|}{ Samples } & & $\begin{array}{c}\text { DMNA } \\
(\mathrm{ppb})\end{array}$ & $\begin{array}{c}\text { Moisture } \\
(\%)\end{array}$ \\
\hline Barley & & n.d. & 8 \\
\hline Green malt & & & 1.0 & 41 \\
Elec. desi. & $50^{\circ}$ & $3 \mathrm{~h}$ & 1.0 & 31 \\
Kilned & $50^{\circ}$ & $3 \mathrm{~h}$ & 5.8 & 34 \\
Elec. desi. & $50^{\circ}$ & $24 \mathrm{~h}$ & 1.1 & 20 \\
Elec. desi. & $70^{\circ}$ & $3 \mathrm{~h}$ & 1.6 & 7 \\
Kilned & $70^{\circ}$ & $3 \mathrm{~h}$ & 8.9 & 7 \\
Elec. desi. & $85^{\circ}$ & $3 \mathrm{~h}$ & 2.3 & 4 \\
Kilned & $85^{\circ}$ & $3 \mathrm{~h}$ & 13.8 & 4
\end{tabular}

n.d., not detected
芽生育過程で反応したものと思われる. 次にこの緑麦芽 を電気乾燥器に入れ, 24 時間 $50^{\circ}$ に加温しても DMNA 生成量は $1.1 \mathrm{ppb}$ でほとんど増加が認められなかった。 さらに 3 時間ずつかけて $70^{\circ}$ および $85^{\circ}$ そ二段階に 温度を上昇させ，それぞれの試料を分析したところ， DMNA はやや増加したものの $1.6 \mathrm{ppb}$ 抢よび $2.3 \mathrm{ppb}$ と 2 倍程度の増加に止まった。

一方，都市ガス焙燥により同様の条件で温度を上昇さ せ DMNA を分析したところ, 温度の上昇とともに生成 量は増加した. すなわち, $50^{\circ}$ では $5.8 \mathrm{ppb}, 70^{\circ}$ では $8.9 \mathrm{ppb}, 85^{\circ}$ では $13.8 \mathrm{ppb}$ の值を示し, 電気乾燥の場 合に比べ数倍高いDMNA 生成が見られた。このことは 長谷川ら ${ }^{13)}$ が明らかにしているよらに都市ガスの然焼に より発生する $\mathrm{NO}_{\mathrm{x}}$ 成分による影響が大きいことを示唆 している.

実際のビール麦芽焙燥温度と同一条件である $85^{\circ}$ 焙燥 により得られた麦芽の DMNA 值 $13.8 \mathrm{ppb}$ は Scheme 1 に示した製造法に用いていた原料麦芽の DMNA 含有

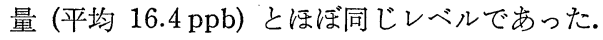

\section{結論}

市販されているほとんどのビールから平均約 $2 \mathrm{ppb}$ の DMNA を検出した。 その DMNA の由来は主原料 である乾燥麦芽に含まれる DMNA が移行したもので あり，この事実はホップの添加，主発酵和よび熟成など 製造工程の各段階においては DMNA の生成増加がみ られなかったことおよび麦芽の焙燥実験により明らかに することができた。

一般に，ビール製造においては使用する乾燥麦芽量に 対して約 9 倍量のビールが作られるが，今回得られた結 果から, 麦芽の乾燥や焙燥の条件を検討することにより 原料麦芽ならびに製品中の DMNA 含有量を少なくす ることができる.

\section{文献}

1) Gough, T.A., Webb, K.S., Coleman, R.F.: Nature, 272, 161 163 (1978).

2) Fine, D. H., Rounbehler, D.P., Belcher, N. M., Epstein, S.S.: Science, 192, 1328 1330 (1976).

3) Fan, T. Y., Goff, U., Song, L., Fine, D. H.: Fd. Cosmet. Toxicol., 15, 423 430 (1977).

4) Fine, D. H., Ross, R., Rounbehler, D. P., Silvergleid, A., Song, L.: Nature, 265, 753 755 (1977).

5) Wang, T., Kakizoe, T., Dion, P., Furrer, R., Varghese, A. J., Bruce, W. R.: ibid., 276, 280 $\sim 281$ (1978)

6) 真木俊夫, 田村行弘, 沜村保洋, 西垣 進, 直井 家壽太: 東京衛研年報. 28-1，145～148 (1977).

7) 真木俊夫, 田村行弘, 嶋村保洋, 西垣 進, 直井 
家壽太：同上，29-1，256２60（1978）.

8）真木俊夫, 田村行弘, 嶋村保洋, 小関正道, 西垣 進, 直井家壽太：同上, 30-1，145１48 (1979).

9) Spiegelhalder, B., Eisenbrand, G., Preussmann, R.: Fd. Cosmet. Toxicol., 17, 29 31 (1979).

10）日本醇造協会編：新版 “酾造成分一覧” p. 215
(1977), 日本酹造協会発行

11) Brauwelt-Report, 5, (1), 137 138 (1979).

12) Drews, B., Just, F., Drews, H.: Proc. European Brewery Conv. 172, 167 172 (1957).

13）長谷川利雄，城戸勝義，小猿和男：公害と対策, 12, (10), 82 92 (1979). 